\title{
A myth? Sustainable tourism as a tool for rescuing traditional spaces: a case study from Turkey, Ankara
}

\author{
Z. Ozcan, N. Ayalp \& G. Guner Aktas \\ TOBB University of Economics and Technology, Turkey
}

\begin{abstract}
The concept of social sustainability should be considered and investigated in developing the conditions of traditional urban spaces. Sustainable tourism can be a basic tool for the physical conservation of architectural heritage. The traditional spaces regain considerable visual and economical value with tourism investments but the social reactions are to the contrary. In the content of the study, two different characteristically spaces were selected in the city of Ankara. The selected urban core was composed of 19th century Ottoman dwellings called "Hamamonu" which have not been considered for a long time. The local municipality developed a project to rehabilitate a part of this area with the help of tourism and left the other part untouched "Hamamarkasi". Social, physical and spatial aspects will be questioned and the opinions of respondents will be output about the rehabilitation project.
\end{abstract}

Keywords: sustainable tourism, traditional space, hamamönü, hamamarkasl.

\section{Introduction}

The oldest urban core of a settlement covers special spaces that help to differentiate it from the others with its original spatial character. In developing countries like Turkey, they are "lost" urban spaces turned to squatter zones, composed of "unpopular" traditional dwellings. Deterioration of the physical space is also the indicator of social change. The new housing zones lead to a social migration from the traditional urban core, leaving the place to lower income groups unaware of their possession responsibilities, resulting in the further collapse of the architectural indoor and outdoor spaces. In several cases, it is observed that not only the physical spaces but also the user profile changes 
when original landowners leave their place to rant groups having limited mental link with traditional life style. While the traditional spaces regain considerable visual and economical value, the social reacts as the contrary.

If it is considered as the only choice of survival, tourism (being a sensitive sector before unexpected variables like catastrophes, terrorism and health problems) affects the fate of architectural heritage. Therefore, "social sustainability" must be considered and investigated in upgrading the conditions of traditional urban spaces by using "sustainable tourism" as a basic tool in physical conservation.

The case study area is chosen as the urban core of Ankara composed of 19th century Ottoman dwellings called "Hamamonu" which are kept out of consideration for a long time. The local municipality developed a project to rehabilitate a part of this area by the help of tourism and left the other part untouched "Hamamarkasi". Therefore there are two different spaces occurred in this region. The paper will discuss the social, physical spatial aspects of the project in the case study.

\section{Basic concepts and recent approaches in sustainable tourism}

The concept of sustainable tourism is defined as "tourism which meets the needs of present tourists and host regions while protecting and enhancing opportunity for the future" in the report of World Tourism Organization in 1993 [1]. McIntyre (1993), also define sustainable tourism as an alternative tourism form that improves the quality of life of the host community, provides a high quality experience for visitors, and maintains the quality of the environment on which both the host community and visitors depend. Moving from those early studies about sustainable tourism, it can be stated that, sustainable tourism seeks to minimize negative impacts on the local culture and natural environment while generating benefits for local residents [2].

The studies of Sirakaya, Tazim and Hwank discusses the concept of sustainable tourism and focuses on the sustainable planning which should focus on balancing the needs and wants of major stakeholders, which requires integrated, dynamic, flexible, detailed, action-oriented strategies that can be applied at national, regional, and local levels. Stakeholder participation and cooperation is a crucial factor of successful sustainable tourism development [3]. Murphy and Ap also posited that residents are major stakeholders in the tourism development process since they are directly affected by tourism regardless of their occupation $[4,5]$.

In the concept of sustainable tourism basic components are critically related to support the positive and negative impacts of tourism. Tourism development should benefit the local communities, strengthens the local economy, employs local workforce and wherever ecologically sustainable, uses local materials, local agricultural products and traditional skills [6]. The declaration of Biodiversity and Tourism in 1997, states that; mechanisms, including policies and legislation should be introduced to ensure the flow of benefits to local communities. 
Tourism activities should respect the ecological characteristics and capacity of the local environment in which they take place. All efforts should be made to respect traditional lifestyles and cultures [7].

As Sirakaya, Tazim and Hwan stated, tourism has been a powerful force for improving domestic economies and providing foreign Exchange Rapid unplanned development, coupled with large numbers of tourists, has caused adverse impacts on cultural and natural resources [3].

Nunkoo, developed a framework which proposed that community attachment, economic gain, utilization of tourism resource base, and environmental attitudes are determinants of the residents' perceived social, economic, and environmental impacts. The model also incorporated two new determinants of attitudes: the state of the local economy and community concern. Further studies expanded on the above models and delineated the impacts into five categories: economic benefits; social benefits; social costs; cultural benefits; and cultural costs. More recently, further built upon the model developed and proposed that the perceived economic, social, and cultural benefits, the perceived social, socioeconomic costs and state of the local economy are determinants of residents' support for mass and alternative forms of tourism [8-11].

Research on residents' attitudes toward tourism suggests that a host population is influenced by the perceived positive benefits of the industry. Tourism increases employment opportunities for the local people improves the local economy, contributes to income and standard of living, brings in new businesses and improves investment opportunities [8-12].

\section{The case study area Hamamönü}

Currently the case study area is located at the southern slopes of the citadel. The wall surrounding the area has been demolished. In fact, the district has been divided into two by a boulevard passing through, as the Hamamönü and Hamamarkas1 (Figure 1). The area owes its name to the Karacabey complex well known with a mosque and a hamam. Depending on its "Pious Foundation Records" the hamam is constructed around 1440 together with a mosque, the tomb of the donor, a fountain and an "imaret" (food delivery building for the poor) [138].

During 1970s and early 1980s, the compact organic urban pattern divided by a boulevard caused to a series of serious problems. The Planning Law of the period, gave the right of constructing high rise apartments located on a building lot composed in the checker-board settlement system at the two sides of such a boulevard. Fortunately, only the two sides of the road could be constructed and the rest of the plan could not be applied anymore, as hundreds of court cases forced the local governors to stop. 


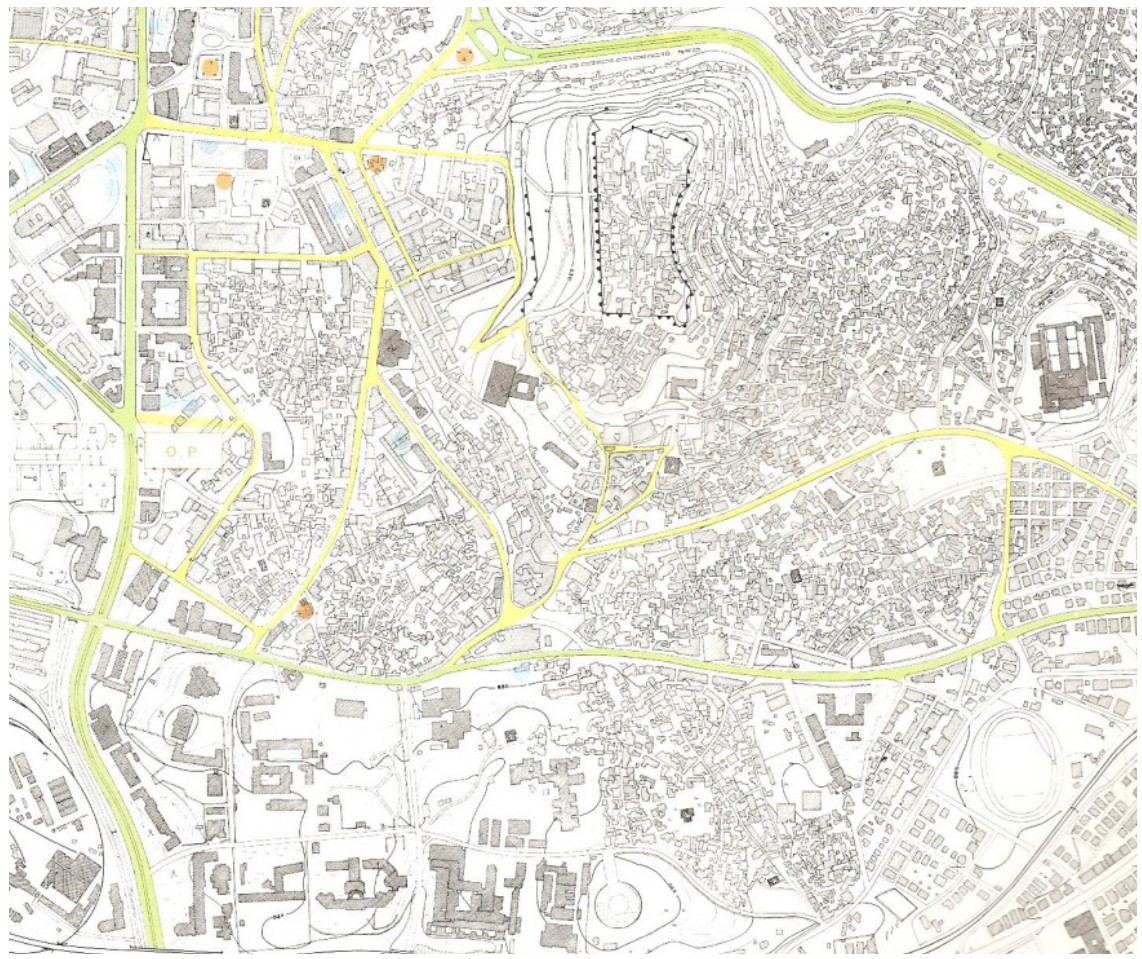

Figure 1: The Hamamönü and Hamamarkası districts with Talat Pasa Boulevard spoiling the urban pattern source: Ankara Kalesi preservation and development master plan, 1987 [14].

In the organic settlement pattern the building lots were small (approximately 70-100sq.m.), mostly amorphous in shape, depending on the topographical limits. In order to achieve a building lot in a grid - iron settlement system of 300-500sq.m. At least 5-10 existing lot should be gathered and expropriated. As the judges could not find logical solutions in a short time, inheritance cases overloaded the situation. Thus, Hamamönü district survived from a complete renewal but, left alone with its fate. As the court cases continued the house owners of the region are stopped to make any change in their properties, even simple mending was prohibited.

In 1980, the traditional houses of the region are registered as cultural properties by the Ministry of Culture. The district got worse in conditions as the registration decision was not supported by social amenities and lacked any financial aid. Not only Hamamönü and Hamamarkası districts but the whole traditional urban fabric of Ankara became a huge problem for the local governments and building owners. The original inhabitants quitted the area and migrated to new housing zones and the new comers were naturally from the lowincome groups or immigrants who could not afford the maintenance of the buildings. The solutionless situation continued for a long time when the 
municipality of Altindag decided to the restoration of the zone. In fact, the first efforts to save the traditional urban fabric dates back to the mid 1990s but they had stayed as minor applications The successful conservation efforts both in Turkiye and abroad led the local municipality to regain the area by the help of" tourism", the two-sided knife.

\section{Characteristics of traditional Ankara houses}

In general the space composition of traditional Ankara houses depends on two categories: the exterior sofa/hall and the interior sofa. Although regional properties can lead to differences, the sofa is indeed the space forming agent of the traditional Ottoman house. The 18th and 19th century Ankara houses share the same characteristics with minor local variations [15] (Figure 2).
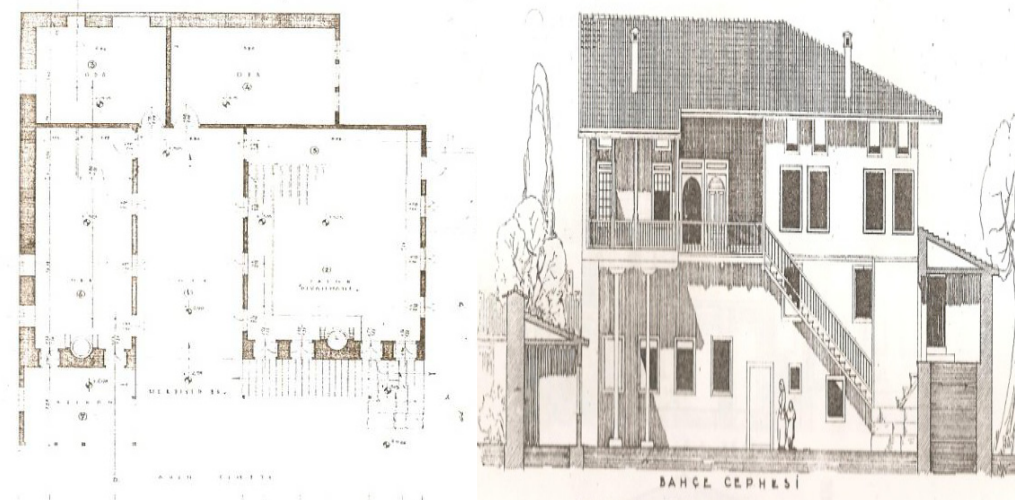

Figure 2: Yusuf Ogras house, plan and section from the courtyard (source: M. Akok, 1946 [16]).

The early examples reflect the exterior sofa plan scheme mostly and the later share the interior sofa. Researchers usually share the idea that the early examples are mostly constructed in the $17^{\text {th }}, 18^{\text {th }}$ and the later in the $19^{\text {th }}$ century [17-19]. It can be stated that the sofa being the main access hall of the house where the other living spaces are connected to, has been a semi-open corridor before the rooms which were heated by fire-places. In fact the exterior-sofa house is composed of a number of rooms aligned at one side of rectangular space while in the interior this space is composed by rooms at longer both sides [20,21] (Figure 3 ). The interior-sofa house can be also deciphered from the outside appearance with a pediment over the projection and high and broad windows at every flat of the house opening not only to the courtyard but also to the streets. The case study district houses are mostly of this type with a variation and combination of both types depending on alterations. 

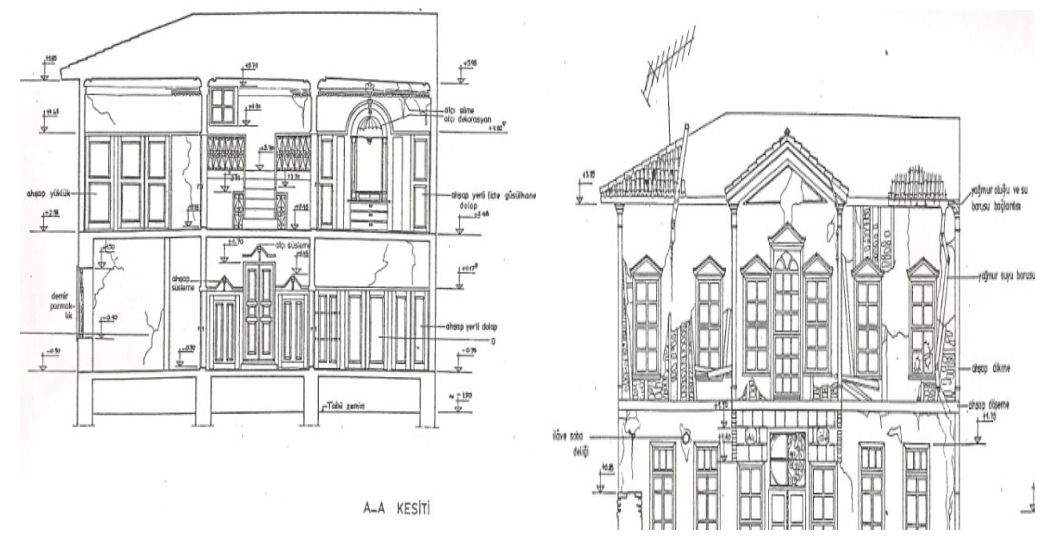

Figure 3: A. Oguz house, section and elevation Source: Z. Ozcan personal archive, 1990.

Whatever type the plan scheme is, the house is always connected with an open space which be described as a paved or semi-paved area. Access to the house can be from this courtyard or directly from the street or a combination of both. The facade of the house easily reveals the plan-scheme as the exterior-sofa can be seen like a balcony all along the elevation facing the courtyard, while the interior sofa is hidden behind a "cumba"/ projection at the midst. Hamamönü district is mainly composed of the latter. Currently, it is fairly difficult to find the exterior-sofa houses because they have either been changed by additional spaces, material alterations or divisions.

\section{Results and findings of study}

Case study area is chosen as the urban core of Ankara composed of 19th century Ottoman dwellings called "Hamamonu" which are rehabilitated for touristic purposes; the other part left untouched "Hamamarkasi". Therefore there are two different spaces occurred in this region. With two different questioner forms, the case study focuses on the problems both within the Hamamonu and Hamamarkas1. The data for the study was obtained by face-to-face meetings by an interviewer in the period of three weeks in 2011. The two responded groups were randomly selected among tourist in Hamamonu and the house owners in Hamamarkas1. At the beginning of the study, the respondents were given brief information about the survey and were asked to give answer to the questions. During the procedure the interviewer filled answers of the questionnaire form for each respondent.

There were 38 house owner respondents from Hamamarkas1. First of all, they were asked to give demographic information. In the second part, the data about the problems of the site were collected. In the third part, their long term plans about the site were asked (if they want to stay or leave the district). In the last part, data about their opinions on the rehabilitated part Hamamonu were 
collected and they were asked if they prefer to have rehabilitation in their district. The problems about the district were considered as lack of parking area, inadequate WC space, lack of open public space and lack of sufficient security. The problem of inadequate WC reported as the most significant one (Figure 4).

\section{Problems About the Site}

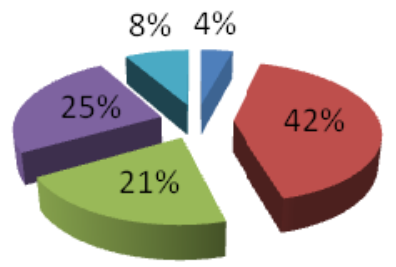

- lack of parking area

inadequatewc

lack of open public space

Figure 4: $\quad$ Problems about Hamamarkası.

All of the participants in Hamamarkas1 visited Hamamonu. 97\% of the participants considered the rehabilitation studies positive. The $87 \%$ of the house owners want to have rehabilitation as in Hamamonu. All of these participants want to rehabilitation studies for having better environmental conditions. The rest was holders worried about if they will be forced to leave for touristic commercial purposes.

In the tourism site Hamamonu, there were 50 tourist respondents. As in the other questionnaire form, firstly they were asked to give demographic information. In the second part, data about their frequency of visit were collected. In the third part, their opinions about the rehabilitation studies were asked. In the last part, they were asked if they want to visit the site again (Figure $5)$.

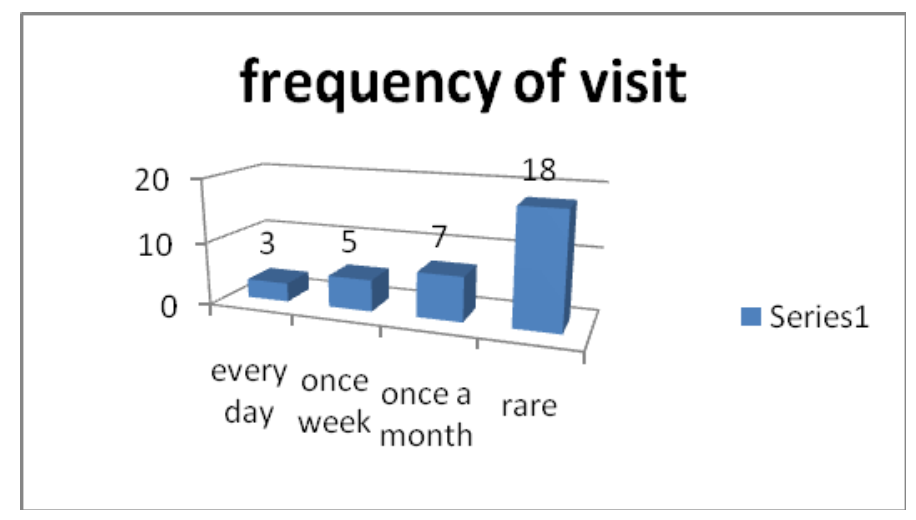

Figure 5: Frequency of visit Hamamonu. 
Most of the respondents considered the rehabilitation studies positive. According to these respondents, with the rehabilitation, security is increased. Moreover, $77 \%$ of the respondents find the study positive in the means of preservation of historic site. Few of the participants considered the studies negative. According to these responds the site became a commercial center and they considered it as a negative fact. Just 1 respondent considered the rehabilitation studies insufficient form the point of lack of open public space (Figure 6).

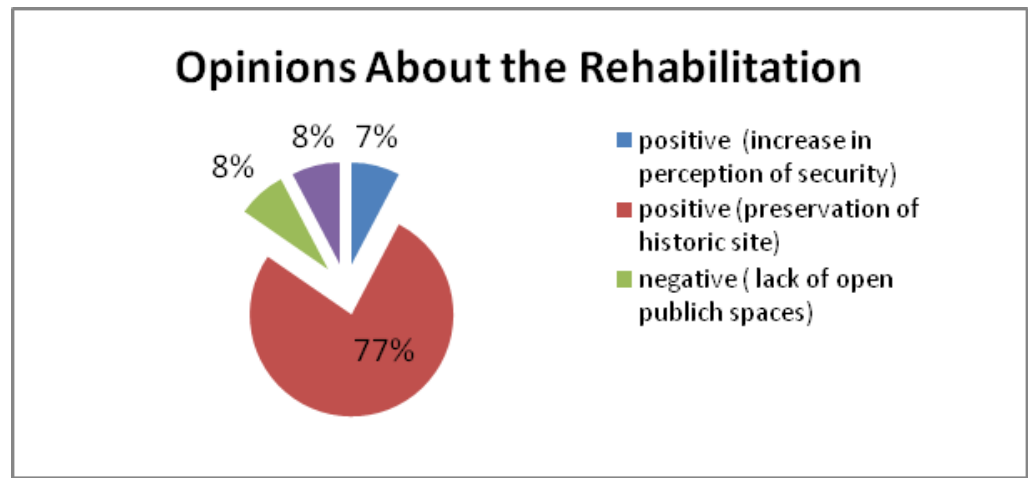

Figure 6: Opinions on the Rehabilitation of Hamamonu.

\section{Conclusion}

As it is discussed; the study mainly focused on the urban core of Ankara composed of 19th century Ottoman dwellings called "Hamamonu" which are kept out of consideration for a long time. Moving from the rehabilitation project of the local municipality; some part of the site to rehabilitate as Hamamonu, the other part left untouched "Hamamarkasi". Consequently In the content of the study, two different regions in the site considered in the context of "social sustainability".

The paper discussed the respondent's opinions on rehabilitation studies of the selected cite, Hamamonu and Hamamarkası. In the results and finings, it's observed that most of the participants consider the tourism area as a development. Another significant output of the study is; the residents of the Hamamarkas1 (untouched area) also prefer a similar rehabilitation in their region. This positive consideration of residents' of Hamamarkası, can be acquired as a sustainable approach in tourism development of the region.

\section{References}

[1] World Tourism Organization. "Sustainable Tourism Development: Guide for Local Planners." Madrid, 1993. 
[2] McIntyre, G., Sustainable Tourism Development: Guide for Local Planners. Madrid: World Tourism Organization, 1993.

[3] Sirakaya, E., Tazim J., and Hwan-Suk C. "Developing Indicators for Destination Sustainability." In The Encyclopedia of Ecotourism, edited by D. B. Weaver. New York: CAB International, pp.411-432, 2001.

[4] Murphy, P., E. “Tourism: A Community Approach.” NewYork: Methuen, 1985.

[5] Ap, J., "Residents Perceptions of Tourism Impacts."Annals of Tourism Research, 19 (4) pp.665-90, 1992.

[6] Clarke, J., “A Framework of Approaches to Sustainable Tourism” Journal of Sustainable Tourism Vol:5, No:3, pp.224-232, 1997.

[7] Biodiversity and Tourism. "International Conference for Environment Ministers for Biodiversity and Tourism". Retrieved November 28, 2009, from http://www.gdrc.org/uem/eco-tour/berlin.html, 2009.

[8] Nunkoo, R. "Developing a Community support Model for Tourism" Annals of Tourism Research, Vol. 38, No:3, pp.964-988., 2011.

[9] Hwansuk C., Iain M., (2010) "Resident Attitudes toward Sustainable Community Tourism" Journal of Sustainable Tourism Vol. 18No. 4 May 2010 pp.575-594, 2010.

[10] Freeman, P., "The Galatian Language, A Comprehensive Survey of the Language of the Ancient Celts in Greco-Roman Asia Minor", The Edwin Mellen Press, N.Y., 2001.

[11] Derbyshire, G. "The Galatian Settlement in Asia Minor", Anatolian Studies Journal, vol.50, pp.75-97, 2000.

[12] Park, E. and Boo, S. "Assesment of Convention Tourism's Potential Contributon to environmentally Sustainable Growth" Journal of Sustainable Tourism, Vol. 18, No:1 January 2010, pp.95-113., 2010.

[13] Ozdemir, R., 19. Yüzyılın İlk Yarısında Ankara, Kültür Bakanlığı Yayını, Ankara, pp.68, 1986.

[14] Ankara Kalesi Koruma Geliştirme İmar Planı Projesi, Altındağ Belediyesi Yayını, Ankara, pp.25, 1987.

[15] Akture, S., 19. Yüzyıl Sonunda Anadolu Kenti Mekansal Yap1 Çözümlemesi, ODTÜ Mimarlık Fakültesi Yayını, Ankara, pp.110-135, 1987.

[16] Akok, M., Eski Ankara Evleri, Ankara Halkevi Yayını, TTK Basımevi, Ankara, pp.11-16, 1946.

[17] Tuncer, M., Ankara Şehri Merkez Gelişimi, Kültür Bakanlığı Yayını, Ankara, pp.30, 2001.

[18] Yavuz, A., 19. Yüzyıl Ankara'sında Kale-içi, Tarih İçinde Ankara, ODTÜ Yayın1, Ankara, pp.156-160, 1984.

[19] Faroqhi, S., Orta Halli Osmanlılar, T. İş Bankası Yayını, Istanbul, pp.29,50,84,85, 2009.

[20] Erdogan, A., Günel, G. and Kilci, A. Tarih İçinde Ankara, Ankara Büyükşehir Belediyesi Yayını, Ankara, cilt 3, pp.33,1998.

[21] Eyice, S., Ankara'nın Eski Bir Resmi, TTK Yayını, "AtatürkKonferansları" IV.ciltten ayrı basım, Ankara, 1972. 